\title{
РОЛЬ И МЕСТО ТИОЦЕТАМА В СТРАТЕГИИ НЕЙРОПРОТЕКЦИИ ПРИ ТЯЖЕЛОЙ ЧМТ И ИШЕМИЧЕСКОМ ИНСУЛЬТЕ
}

* Черний В.И.

Донецкий нацииональный медищинский университет им. М. Горького

Ключевые слова: тиацетам, ишемический инсульт, черепно-мозговая травма

$\mathrm{C}$ овременные патофизиологии ишемического мозга свидетель- ствуют о патогенетическом единстве механизмов клеточного повреждения при любой острой церебральной недостаточности (ОЦН), что обусловлено обязательно возникающей тканевой ишемией [1].

Недостаточно эффективное лечение тяжелой черепно-мозговой травмы (ЧМТ), мозгового инсульта и глобальной ишемии мозга требует пересмотра стратегии нейропротекторной терапии [2]: первичная нейропротекция должна быть направлена в первую очередь на восстановление реологических свойств крови, микроциркуляции, эндотелиальной дисфункции, функционального состояния нейроглии и ГЭБ, то есть на участки белого вещества, а не серого. А после этого осуществля- ется вторичная нейропротекция, влияющая в основном на нейроцит [3].

В связи с накопленными данными о роли воспаления в процессе вторичного повреждения мозговой ткани при ишемии мозга, травме и кровоизлиянии актуальным является вопрос о возможных путях фармакологической коррекции этой реакции. Начиная с первых дней заболевания, после формирования морфологических инфарктных изменений в веществе мозга, все большее значение приобретает репаративная терапия, направленная на улучшение пластичности здоровой ткани, окружающей инфаркт мозга, активацию образования полисинаптических связей, увеличение плотности рецепторов [4].

Одной из универсальных составляющих патогенеза повреждения нервной ткани *e-mail: vicerectorDNMU@yandex.ua является трофическая дисрегуляция, приводящая к биохимической и функциональной дифференциации нейронов с инициированием каскада патобиохимических процессов [5]. Традиционно в ангионеврологии применяется ряд препаратов, влияющих на нейропластические, нейромедиаторные, нейропротекторные, нейротрофические и интегративные процессы в мозге. Что же имеется в виду под этими терминами? Под нейропластичностью понимается процесс постоянной регенерации пораженного мозга, адаптирующий нервную систему к новым функциональным условиям. Под нейропротекцией - активизация метаболических процессов в головном мозге, противодействующих повреждающим факторам. Под нейротрофикой понимается процесс пролиферации, миграции, дифференциации нервных клеток [5].

Вторичные нейропротекторы, обладающие трофическими и модуляторными свойствами (нейропептиды), оказывают и регенераторнорепаративное действие, способствуя восстановлению нарушенных функций. Наряду с ними к средствам репаративной терапии от носятся производные гаммааминомасляной кислоты (ГАМК) ноотропы, особенно при наличии очагового неврологического дефекта [4].

Н.Е. Иванова, В.С. Панунцев [6] указывают, что уровень трофического обеспечения вещества мозга влияет на механизмы некротических и репаративных процессов. Даже при сформировавшемся очаге ише-миивысокий уровеньтрофического обеспечения способствует регрессированию неврологического дефи- цита [6].

Поэтому ключевым моментом в интенсивной терапии ишемии мозга, 
обусловленной как тяжелой ЧМТ, так и мозговым инсультом, является активация процессов репарации нервной ткани. Препараты, влияющие на процессы нейропластичности, занимают одно из ведущих мест в терапии ишемии головного мозга [7].

В структуре терапевтических воздействий при церебральной ишемии ведущую роль играют два основных направления [8]: 1) улучшение гемодинамики с целью компенсации нарушенного мозгового кровообращения и адекватного обеспечения структурмозгаэнергетиче-скимисубстратами и кислородом; 2) защита нейронов от ишемии, сохранение их структуры, целостности и функциональной активности.

Группы фармакологических препаратов, которые применяют с целью сохранения функции головного мозга, к настоящему времени все более узко специализированы для решения конкретных патогенетических задач, однако их эффективность как в эксперименте, так и в клинической практике неоднозначна. В дальнейшем в соответствии c гипотезами токсичности возбуждающих аминокислот и кальциевой гибели нейронов при фокальной ишемии мозга было разработано большое число препаратов, влияющих на эти механизмы клеточного повреждения $[2,8]$.

Направления патогенетической нейропротекторной терапии ишемии головного мозга существуют, но клинические испытания, проверяющие множество потенциальных нейропротекторных веществ, дали отрицательные или разочаровывающие результаты $[5,6,8]$.

$$
\text { Среди всего }
$$

многообразия фармакологических препаратов, которые используются в ежедневной практике, не так много реально востребованных в терапии больных тяжелойпатологией нервной системы и получивших клиническую оценку. Среди препаратов или методов нейропротекции, различная степень эффективности которых относительно подтверждена данными рандо- мизированных исследований, можно выделить гипотермию, раствор альбумина, церебролизин, цитиколин, сернокислую магнезию, глицин и пирацетам.

В последние годы в связи с прогрессом в области нейрохимии, молекулярной биологии, экспериментальной и клинической фармакологии появилось большое число исследований, в том числе клиникофармакологических, позволяющих с современной точки зрения представить механизм действия и области применения ноотропных препаратов. Особенно много работ посвящено изучению пирацетама, который до настоящего времени остается эталонным ноотропным препаратом.

Хорошо изучены фармакологические эффекты пирацетама. Его мембраностабилизирующий эффект прояв ляется уменьшением микровязкости мембран нейронов, нормализацией проницаемости фосфолипидного слоя мембран нейронов и соотношения холестерин/фосфо- липиды. Пирацетам активирует естественную антиоксидантную систему организма - каталазу и супероксиддисмутазу. Антигипоксический эффект достигается за счет стимуляции альтернативныхпутей метаболизмавусловиях гипоксии - пентозофосфатного и гексозофосфатного, нормализации процессов окислительного фосфорилирования, накопления макроэргических соединений (АТФ), что обеспечивает поддержание полноценного уровня тканевого дыхания. Белоксинтетический эффект осуществляется стимуляцией транскрипции генов, ответственных за белковый синтез в нейронах. Это приводит в том числе и к активации межполушарного обмена информацией за счет развития межнейронных связей, улучшению памяти и способности к обучению. Нейромедиаторный эффект достигается за счет влияния пирацетама на систему ионных ка- налов $\mathrm{Na}+, \mathrm{K}+, \mathrm{Ca} 2+$, активации синтеза ацетилхолина и М-холинорецепторов, синтеза серотониновых, дофаминовых и адренорецепторов, высвобождения глутамата и, как следствие, нормализации нейромедиаторного дис-баланса

Вазотропный эффект проявляется ослаблением спастических реакций 
гладкомышечных клеток сосудов мозга, уменьшением вязкости плазмы и цельной кровизасчет сниженияагрегациитромбоцитов и степени их адгезии к эндотелию сосудов мозга, оптимизации процессов мозгового кровообращения.

Биодоступность пирацетама составляет около 100 \%, он не связывается с белками плазмы крови, проникает через гематоэнцефалический барьер, накапливается в мозговой ткани, во внутренних органах. Избирательно накапливается в тканях коры головного мозга, преимущественно в лобных, теменных и затылочных долях, в мозжечке и базальных ганглиях. В организме пирацетам практически не подвергается биотрансформации и выделяется преимущественно почками в неизмененном виде. В течение 24-30 часов после однократного приема выделяется 90100 \% введенной дозы препарата.

В настоящее время пирацетам рекомендуют использовать при лечении мозгового инсульта, тяжелой ЧМТ, тяжелых интоксикаций с поражением ЦНС. Пирацетам рекомендуют для лечения коматозных состояний после перенесенных инсультов, травм и интоксикаций головного мозга как в остром периоде, так и в периоде восстановительной терапии после этих состояний. Причем при лечении коматозных состояний у больных с травмами головы, инсультом рекомендуемая начальная доза составляет 9-12 г/сутки, поддерживающая - 4,8-2,4 г/ сутки [9].

Однако это спорное положение, так как у пирацетама существует побочное действие. Препарат может вызывать повышенную раздражительность, возбудимость, нарушение сна, диспептические расстройства, повышенную двигательную активность, у больных пожилого возраста изредка отмечается обострение коронарной недостаточности. Изредка сообщается о головокружении, головных болях и повышении сексуальности. У некоторых больных отмечаются слабость и сонливость. В большинстве случаев удается добиться регрессирования подобных симптомов, снизив дозу препарата.
Особые меры предосторожности необходимо соблюдать при применении препарата у больных в коматозных состояниях. Кома является противопоказанием к применению средств, обладающих стимулирующим действием (психостимуляторов, дыхательных аналептиков, ноотропов). Ноотропные препараты (пирацетам) вызывают психомоторное возбуждение и противопоказаны при нарушениях сознания глубже оглушения - сопора. При любом коматозном состоянии независимо от глубины церебральной недостаточности применение средств, возбуждающих ЦНС (препараты из группы ноотропов), не рекомендуется, так как они приводят к растормаживанию подкорковых структур, вызывают психомоторное возбуждение или судороги, еще больше угнетая кору [7, 8, 10]. Таким образом, вопрос об использовании ноотропов с нейропротекторными свойствами у больных с тяжелой ЧМТ и мозговым инсультом, осложненными коматозным состоянием, является актуальным.

Решение данной проблемы - оптимизация фарма- котерапии за счет применения комбинированных нейротропных средств. Нам представляется перспективным применение нового церебропротекторного препарата, представляющего собой комбинацию пирацетама с тиотриазолином. Тиотриазолин обладает соответствующими фармакологическими (высокая антиоксидантная, противоишемическая активность), фармакотехнологическими (совместимость с другими препаратами) и фармакоэкономическими характеристиками [11].

Наибольшей активностью обладает комбинация 0,05 г тиотриазолина и 0,2 г пирацетама. На основании нее была разработана лекарственная форма — таблетки и ампулы Тиоцетам.

Эта комбинация первоначально отобрана из экспериментальной серии на основании четкого противоишемического, антиоксидантного и антиамнестического эффектов. Результаты экспериментальных исследований, полученных в условиях 
«конфликтной ситуации», создаваемой столкновением питьевого и оборонительного рефлексов, показали, что Тиоцетам обладает не только выраженным антиамнестическим действием (сохранность условного рефлекса пассивного избегания), но и антистрессорным действием, сохраняя ориентировочную активность животных, их двигательную активность, адекватность реагирования, снижая беспокойство и тревожность. Пирацетам в этом тесте оказывал достоверно менее (в 2,5 раза) выраженный антиамнестический эффект и не обладал антистрессорным действием, a тиотриазолин не оказывал достоверного фармакологического действия [12-14].

При последующем изучении комбинация 0,05 г тиотриазолина и 0,2 г пирацетама продемонстрировала широкий спектр церебропротекторных и ноотропных эффектов. Об этом свидетельствует целый ряд экспериментальных исследований (И.Ф. Беленичев и соавт.): благоприятное воздействие на физическое и психическое развитие недоношенных крысят (Тиоцетам повышал выживаемость недоношенных крысят в первые 7 суток жизни и на 71,4 $\%$ достоверно превосходил пирацетам, на $65 \%$ - тиотриазолин в этом тесте), Тиоцетам устранял нарушение когнитивномнестических функций у недоношенных животных, улучшая показатели кратковременной и долговременной памяти, активируя ориентировочно-исследовательскую активность (Тиоцетам значительно улучшал процессы биоэнергетики, углеводный обмен, синтез белка в головном мозге недоношенных крысят). Доказана эффективность Тиоцетама при различных формах ишемии мозга (острое нарушение мозгового кровообращения (ОНМК), вызванное перевязкой наружных сонных артерий, а также внутримозговое кровоизлияние (ВК), вызванное введением аутокрови во внутреннюю капсулу головного мозга). Тиоцетам достоверно повышал выживаемость животных с ОНМК и ВК на 55-70 \%, пирацетам повышал этот показатель на 25-35 \%, а тиотриазолин - на 40-55 \%. После моделирования ОНМК и ВК Тиоцетам значительно снижал угнетение безусловных рефлексов на световые, звуковые и болевые раздражители, достоверно уменьшал нарушения неврологического статуса, улучшал двигательную и ориентировочноисследовательскую активность [14].

Введение Тиоцетама приводило к улучшению картины общей гистоструктуры мозга, что выражается в снижении явлений периваскулярного, перицеллюлярного и апикально-дендритного отеков, уменьшении числа ишемически измененных нейронов, также уменьшалось число спавшихся капилляров. Тиоцетам значительно активирует пролиферацию клеток глии и их функцию, вызывает усиление сателлитоза, что является ведущим фактором обеспечения жизнедеятельности нейронов при развитии ишемических повреждений головного мозга. Увеличивается по сравнению с контролем количество клеток астроглии на единицу площади: в 5-6 раз на фоне применения Тиоцетама, в 3-4 раза - при использовании тиотриазолина. Назначение пирацетама в этих экспериментальных условиях оказывало умеренное действие [12-14].

Тиоцетамувеличивалскорость элиминации погибших нейронов, по всей видимости, вследствие стимуляции активности микроглиальных клеток мозга, тиотриазолин оказывал более умеренное действие, а пирацетам не оказывал достоверного эффекта [12].

Тиоцетам вызывал ослабление процессов нейрональной гибели в сенсомоторной зоне фронтальной коры и CA1 зоны гиппокампа (в 2,3-2,5 раза) в острый период ОНМК. Тиотриазолин вызывал снижение нейрональной гибели в сенсомоторной зоне коры почти в два раза и в 1,4 раза в гиппокампе, а пирацетам приводил к усилению нейрональной гибели, особенно в гиппокампе. Введение Тиоцетама снижало долю функционально неактивного гетерохроматина в 1,75-2,8 раза в ядрах нейронов лобной коры и гиппокампа. Это свидетельствовалоозначительнойстимуляции генной активности и об активации процессов трансляции. Тиотриазолин оказывает более 
умеренное действие в этом отношении, а пирацетам его практически не оказывает. Тиоцетам, тиотриазолин и пирацетам приводили к достоверному снижению частоты случаев цитолиза нейронов в коре и гиппокампе. При этом степень снижения частоты цитолиза была выше у Тиоцетама. Причиной появления подобного действия у Тиоцетама могло служить то, что механизм церебропротекторного действия данного комбинированного препарата в значительной степени обусловлен взаимопотенцированием антиоксидантных (влияние на активность антиоксидантных ферментов и образование активных форм кислорода) и энерготропных (влияние на малат-аспартатный челнок, окисление в цикле Кребса, гликолиз) свойств. Тиоцетам тормозит истощение запасов глюкозы и гликогена в нейроцитах в острый период ОНМК и ВК. Одновременно уменьшает гиперпродукцию лактата (в отличие от пирацетама, который усиливает развитие лактатацидоза в острый период ишемии), нормализует активность глюкозо-6-фосфатдегидрогеназы. Показатели окислительной продукции энергии (НАД/ НАДН, цитохром-С-оксидаза, уровень пирувата, малата и изоцитрата) превосходят уровень контроля, тиотриазолина и пирацетама. Поддержание Тиоцетамом окислительного углеводного метаболизма определяет повышение уровня макроэргических фосфатов (АТФ и креатинфосфата). Пирацетам в этих условиях оказывал преимущественное влияние на анаэробные пути образования энергии, увеличивая содержание лактата в тканях мозга, которое превышает таковое в контрольных группах. Тиоцетам в большей степени, чем пирацетам, корригирует нарушения биоэнергетики мозга при ОНМК преимущественно за счет восстановления аэробных путей продукции энергии [12-14].

Тиоцетам, не оказывая влияния на уровень белка в цитоплазме и митохондриях ишемизированных нейронов, существенно тормозил нарастание фонда свободных аминокислот и их нейродеструктивное действие. Тиоцетам значительно увеличивал уровень
РНК в ядрах нейронов коры и гиппокампа животных с ОНМК и ВК, что указывает на активацию процессов протеинсинтеза и является адаптационной реакцией на гипоксию, обеспечивающей перестройку метаболизма мозга без повышения потребности в кислороде. Пирацетам не оказывал выраженного влияния на процессы синтеза РНК в тканях мозга [12].

Тиоцетам тормозил активность свободнорадикальных реакций в ишемизированном мозге, достоверно снижая накопление биотоксических продуктов (альдегидов, кетонов). Тиоцетам увеличивал активность антиоксидантных ферментов (супероксиддисмутаза, каталаза, глутатионпероксидаза), повышал фонд а-токоферола. Антиоксидантный эффект пирацетама был значительно хуже и реализовался за счет влияния на элементы «второго эшелона» антиоксидантной защиты (глутатионпероксидаза, а-токоферол) [12, 14].

Таким образом, анализируя данные И.Ф. Беленичева и соавт., можно сделать вывод, что в отношении таких механизмов церебропротекторного действия, как антиоксидантный, противоишемический, антиамнестический, Тиоцетам выгодно отличается от пирацетама идругих препаратов рацетамного ряда и производных ГАМК [12-14].

Экспериментальными исследованиями доказано, что фармакологический эффект Тиоцетама обусловливается взаимопотенцирующим действием тиотриазолина и пирацетама. Комплексный препарат Тиоцетам, разработанный украинскими учеными, увеличивает интенсивность функционирования метаболического ГАМК-шунта и концентрацию ГАМК в ишемизированных тканях, нормализует нейромедиаторный (дофамин- и норадренергический) обмен, снижает выраженность вестибулярных расстройств, улучшает ассоциативные процессы, интегративную деятельность мозга, стимулирует процессы мышления и памяти, улучшает способность к концентрации 
и обучению. Он ускоряет утилизацию глюкозы при аэробном и анаэробном пути окисления, увеличивает фонд АТФ, стабилизирует церебральный метаболизм, тормозит свободнорадикальные процессы в тканях мозга, реактивирует ферментативную антиоксидантную систему (СОД), улучшает реологические свойства крови, стабилизирует и уменьшает зоны некроза и ишемии, стимулирует пластические и биоэнергетические процессы в нервной ткани.

На основании данных литературы и опыта кафедры анестезиологии, интенсивной терапии и медицины неотложных состояний ФИПО Донецкого национального медицинского университета им. М. Горького и отделения нейрореанимации областного нейрохирургического центра ДОКТМО можно рекомендовать следующий принцип терапии нейротропными препаратами при острой церебральной недостаточности: учитывать фазы течения постгипоксической энцефалопатии [8].

Фазы течения постгипоксической энцефалопатии

I. Острая фаза (катаболическая фаза):

a) активация обменных процессов либо их торможение, если происходит срыв адаптации (1-е - 3-и сутки восстановительного периода);

б) гипоэргоз - развитие энергетического дефицита преимущественно в клетках ЦНС (максимальное развитие на 2-5-е сутки);

в) эндогенная интоксикация интрацеребрального и экстрацеребрального генеза (максимальное развитие на

6-10-е сутки).

II. Фаза стабилизации:

a) устойчивая стабилизация гомеостаза (анаболическая фаза) (месяцы, годы);

б) неустойчивая стабилизация гомеостаза (напряжение и истощение адаптационных процессов) (недели, месяцы).

С учетом фазы течения постгипоксической энцефалопатии препараты, влияющие на мозговой метаболизм, еще недавно вводились в следующей последовательности:

1. Антигипоксанты (оксибутират натрия, стадол, бензодиазепины и т.п.) - в фазу
Ia при тяжелых формах энцефалопатии, протекающей с «неэкономичным» энергетическим метаболизмом мозга.

2. Прямые антигипоксанты (стимуляторы аэробного метаболизма)(цитомак, актовегин), применяются в остром периоде в фазы Іа, Іб, IB.

3. Ноотропные и ГАМКергические средства, стимулирующие энергетический метаболизм, начинают применяться только в фазе Іб, Ів или в фазе II. Все средства метаболического действия вводятся под контролем ЭЭГ и в первой половине дня.

4. Препараты нейромедиаторного, нейрорецепторного, нейротрофического действия. В фазе I обычно не использовались, а назначались в фазе стабилизации (фаза II). В настоящее время начали применяться в фазе Ia.

Если состояние пациента с острой травмой или ишемией головного мозга оценивается как тяжелое или крайне тяжелое (оценка по шкале комы Глазго от 4 до 8 баллов), то первоочередными мероприятиями нейропротекции будут экстрацеребральные воздействия и применение методов и препаратов, снижающих энергетический и биохимический потенциал работы нейроцитов (аналгоседация). Анальгезия и седация являются неотъемлемыми компонентами современной терапии острого периода ЧМТ. Применение компонентов анальгезии и седации, объединенных методологически и разделенных фармакологически, в рамках единой схемы аналгоседации имеет патофизиологическую основу и прямые клинические показания. Уменьшая мозговой метаболизм и потребность мозга в кислороде, а также сводя к минимуму болевые стимулы как из зон травматических повреждений, так и при необходимых терапевтических манипуляциях, аналгоседация занимает одно из мест в единой терапевтической концепции последовательной терапии тяжелой ЧМТ [14]. Основными клиническими показаниями для аналгоседации при острой, тяжелой ЧМТ являются необходимость адекватного функционирования системы «пациент - респиратор», моторное возбуждение 
больного, гипертензия и тахикардия. Но вопрос объективного контроля за глубиной аналгоседации по-прежнему актуален, в том числе для профилактики поверхностной или, напротив, чрезмерно глубокой аналгоседации.

Снижение повреждающего действия гипоксии на структуры головного мозга происходит путем торможения мозгового метаболизма со снижением энергетической потребности нейронов (антигипоксанты).

Антигипоксанты, снижающие энергетические потребности мозга (оксибутират натрия, стадол, бензодиазепины (мидазолам) и т.п.), применяются при тяжелых формax энцефалопатии, протекающей с «неэкономичным» энергетическим метаболизмом мозга. При использовании антигипоксантов, снижающих энергетические потребности мозга, наиболее перспективным, по нашему мнению, следует признать применение оксибутирата натрия.

Параллельно с антигипоксантами, снижающими энергетические потребности мозга, необходимо применение так называемых прямых антигипоксантов (стимуляторов аэробного метаболизма), влияющих на тканевый обмен путем увеличения утилизации кислорода и глюкозы, улучшения тканевого дыхания (цитомак, актовегин и т.п.). Необходимо также применение препаратов нейромедиаторного, нейрорецепторного, нейротрофического действия, которые в недалеком прошлом использовались только в восстановительном, реабилитационном периоде (цереброкурин, церебролизин, цитиколин, семакс).

При общем состояниипациента, оцененном ближе к среднетяжелому (оценка по шкале комы Глазго более 8-9 баллов), необходимо дополнение терапии ноотропными (пирацетам и др.) и продолжение терапии нейрометаболическими препаратами. Именно в этот период болезни начинают применяться ноотропные и ГАМКергические средства, стимулирующие энергетический метаболизм. Ноотропы - вещества, которые активируют высшую интегративную деятельность мозга, восстанавливают нарушенные мнестические и мыслительные функции, снижают неврологический дефицит и повышают резистентность организма к экстремальным воздействиям. Но необходима определенная структурная целостность ткани мозга и соответствующий уровень функциональной активности мозга для реализации эффекта ноотропов, стимулирующих энергетический метаболизм. Поэтому пирацетам в средней дозе 30-200 мг/кг в сутки применяется при глубине нарушения сознания более 9-10 баллов по шкале комы Глазго. Но Тиоцетам, который сочетает ноотропные, мнемотропные, антигипоксические свойства пирацетама с противоишемическими, антиоксидантными и мембраностабилизирующими свойствами тиотриазолина, выгодно отличается отпирацетама и других аналогичных ноотропов. Он может и должен применятся во всех периодах течения острого церебрального нарушения, но эффект может быть дозозависимым.

В интенсивной терапии острой церебральной недостаточности, обусловленной тяжелой черепно-мозговой травмой или мозговым инсультом, актуальной остается проблема определения сроков начала лечения Тиоцетамом и критериев выбора оптимальной дозы Тиоцетама с помощью методаинтегрального количественного анализа ЭЭГ-паттернов и изучения реактивности мозга [15].

Наши предыдущие исследования были посвящены определению объективных критериев оценки эффективности применения церебропротектора Тиоцетама с помощью метода интегрального количественного анализа (ИКА) ЭЭГ-паттернов и изучения реактивности мозга в ответ на применение препарата $[15,17,18]$.

Изучение типов реакции ЦНС в ответ на фармакологическое воздействие дало возможность количественно оценить увеличение или уменьшение дезорганизации ЭЭГ-паттерна и определить уровень нейрофизиологического воздействия препарата на мозг (кора - подкорка, кора кора).

В результате проведенных исследований были определены типы реакций ЦНС в 
ответ на фармакологичекое воздействие введение Тиоцетама [15].

I тип - отсутствие достоверных изменений показателей абсолютной спектральной мощности и интегральных коэффициентов (прогностически неблагоприятный).

II тип, подгруппы(ПГ) 1a, 16 - увеличение спек-тральной мощности (CM) ЭЭГ-паттерна преимущественно за счет повышения абсолютной $\mathrm{CM}$ (ACM) патологических дельта- и тетадиапазонов (прогностически неблагоприятный); подгруппа 1в - увеличение СМ ЭЭГ-паттерна преимущественно за счет повышения АСМ альфа-активности (прогностически благоприятный). Реакции II типа отражают изменения корковоподкорковых взаимодействий в ответ на фар- макологическое воздействие $[17,18]$.

Реакции ЦНС типа II 1а и II 16 ПГ отнесены к про- гностически неблагоприятным, так как они характеризуются нарастанием дезорганизации ЭЭГ-паттерна за счет недостаточности стволовых активирующих влияний с увеличением спектральной мощности патологической, преимущественно $\delta$-волновой активности.

II тип, подгруппы 2a, 26 - уменьшение СМ ЭЭГ- паттерна преимущественно за счет угнетения $\delta$ - и $\theta$-ритмов (прогностически благоприятный). Из реакций II типа наиболее благоприятной следует считать II 2a ПГ изменений, отражающих, во-первых, рост активирующих влияний на кору со стороны ретикулярной формации и, во-вторых, характеризующихся угнетением патологической активности $\delta$ - и $\theta$-диапазонов.

III тип, подгруппы 1a, 16 перераспределение мощности за счет активации $\delta$ - и $\theta$-ритмов и угнетения $\alpha 1$ активности (относительно неблагоприятный). Ре- акции перераспределения подгрупп III 1а и III 16 мож- но назвать относительно неблагоприятными, так как они свидетельствуют об относительном восстановлении функции нейронов в условиях обширных морфоструктурных постишемических повреждений клеток мозга, но отражают умеренные дезорганизационные ЭЭГ-

Таблица 1. Варианты ответа ЦНС на фармакологическое воздействие - введение Тиоцетама у пациентов с ЧМТ и мозговым инсультом

\begin{tabular}{|l|l|}
\hline $\begin{array}{l}\text { Тип фармакологической реакции на } \\
\text { введение Тиоцетама }\end{array}$ & Тактика применения Тиоцетама \\
\hline III 2a, III 3a, II 2a, II 2б и III 2б подгруппы & Адекватная доза Тиоцетама \\
\hline III 3б подгруппа & Необходимость повышения дозы Тиоцетама \\
\hline I, III 1а и III 1б подгруппы & Необходимость подбора дозы Тиоцетама \\
\hline II 1а, II 1б подгруппы & $\begin{array}{l}\text { Необходимость уменьшения дозы Тиоцетама } \\
\text { или отмена препарата }\end{array}$ \\
\hline
\end{tabular}

процессы. III тип, подгруппы 2a, $26-$ перераспределение ЭЭГ-мощности с активацией мощности $\alpha$ - и $\beta 2$-диапазонов за счет редукции дельта-активности (прогностически благоприятный). Реакции III типа — изменения взаимодействий на уровне коры мозга в ответ на фармакологическое воздействие.

Из реакций перераспределения мощности (III тип) прогностически благоприятными можно считать подгруппу изменений III $2 \mathrm{a}$, для которой типична активация $\alpha$ - и $\beta 2$ ритмов за счет угнетения дельта-активности. Возможно, такие реакции, особенно на стороне поражения, отражают корковые процессы восстановления обратимо поврежденных клеток мозговой ткани, их постсинаптической пропускной способности для высокочастотной стимуляции.

III тип, подгруппы 3a, 36 перераспределение ЭЭГ- активности с увеличением $\beta 2$-мощности за счет редукции $\delta$-ритма (прогностически благоприятный). Реакции III типа - изменения взаимодействий на уровне коры мозга в ответ на фармакологическое воздействие. Интересны реакции III 3а ПГ, для которых характерно замещение альфа-ритма высокочастотной $\beta 2$ - 
активностью, что считается ЭЭГ-коррелятом перехода от состояния покоя к напряжению при умственной деятельности у взрослых.

Факторами, влияющими на эффективность интен- сивной терапии Тиоцетамом, являются, с одной стороны, функциональная сохранность церебральных структур, нейромедиаторных и метаболических механизмов, участвующих в функциональном ответе, а с другой - доза Тиоцетама.

Используя определение типа реакции ЦНС в ответ на введение Тиоцетама, возможно оценить адекватность применяемой дозы препарата и необходимость ее коррекции (табл. 1).

Так, адекватной может считаться доза Тиоцетама, после которой выявлены изменения III 2a, III 3a, II $2 \mathrm{a}$ и III 26 подгрупп.

Фармакологической реакцией, свидетельствующей о необходимости повышения дозы Тиоцетама, следует считать III 36 ПГ изменений.

Тактикапривыявленииизмененийподгрупп III 1а и III 16 должна быть следующей: подбор дозы препарата с обязательной интегральной оценкой ЭЭГ-паттерна после введения препарата.

Необходимо уменьшить дозу вводимого препарата при изменениях, относящихся к подгруппам II 1a, II 1б, II 26.

Таким образом, с помощью метода ИКА ЭЭГ может быть выявлена степень функционального поражения или функциональной сохранности церебральных структур при ОЦН, определяющая в конечном итоге уровень сознания больного. Однако в практической деятельности врач интенсивной терапии, анестезиолог и невропатолог не в состоянии провести ЭЭГ-картирование и применить метод ИКА. Поэтому в клинической практике выбор вводимой дозы Тиоцетама должен быть ориентирован на уровень сознания (или на степень его нарушения).

Нами разработана методика определения адекватной дозы Тиоцетама на основе сопоставления метода оценки нарушения сознания по шкале комы Глазго и метода интегрального количественного анализа уровня дезорганизации ЭЭГ-паттерна с исследованием реактивности мозга в ответ на введение Тиоцетама. Начиная с первыхвторых суток после травмы исследуют реактивность мозга на введение Тиоцетама. Вводят 5 мл препарата - начальная доза и по изменению электроэнцефалограммы, записанной до начала введения и через 20-30 минут после окончания введения Тиоцетама, определяют тип реакции ЦНС.

Если типы реакций на введение свидетельствуют об увеличении дезорганизации ЭЭГ-паттерна, то введение препарата прекращают, но на следующий день исследование повторяют и т.д.

Если типы реакций на введение начальной дозы Тиоцетамасвидетельствуют об уменьшении дезорганизации ЭЭГпаттернаили не изменяются, дозу повышают еще на 5 мл и т.д. до момента увеличения дезорганизации ЭЭГ-паттерна. После этого возвращаются на предыдущую дозу, ее оставляют. Тестируют на следующий день на адекватной дозе (не вызывающей усиление дезорганизации) и т.д. Параллельно проводят оценку нарушения сознания по шкале комы Глазго и коррелляционный анализ между примененной дозой Тиоцетама и уровнем сознания по шкале комы Глазго (баллы), количественными показателями ЭЭГ (интегральные показатели). В результате будет рекомендована доза препарата в зависимости только от результатов исследования уровня сознания по шкале комы Глазго. Такой подход позволит с большой степенью чувствительности судить о действии Тиоцетама при той или иной степени нарушения сознания (оглушение сопор - кома).

\section{Выводы}

1. Церебропротекторное действие (антиоксидантное, противоишемическое, антиамнестическое) Тиоцетама выгодно отличается от пирацетама и других препаратов рацетамного ряда и производных ГАМК.

2. В интенсивной терапии острой церебральной недостаточности, обусловленной тяжелой черепно-мозговой травмой или 
мозговым инсультом, актуальной остается проблема определения сроков начала лечения Тиоцетамом и критериев выбора оптимальной дозы препарата.

3. Выбор начальной дозы Тиоцетама у пациентов с ЧМТ и ОНМК должен быть дифференцированным и проводиться под нейрофизиологическим контролем.

4. Включение препарата в комплекс

\section{СПИСОК ЛИТЕРАТУРЫ}

1. В ramlett H.M., Dietrich W.D. Патофизиология ишемическо- го и травматического поражения мозга: сходства и различия // Медицина неотложных состояний. - 2006. - № 4(5). - С. 32-36;

№ 5(6). - С. 36-43.

2. Гусев Е.И., Скворцова В.И. Ишемия головного мозга. - М.: Медицина, 2001. - 328 с.

3. Черний В.И., Островая Т.В., Андронова И.А., Городник Г.А. Современная стратегия церебропротекции: коррекция эндоте- лиальной дисфункции ГЭБ // Біль, знеболювання i інтенсивна терапія. — 2008. — № 2-д. Матеріали V Національного конгресу анестезіологів України 08-12 вересня, м. Київ. - С. 358-360.

4. Дьяконов М.М., Скоромец А.А. Фармакология - практи- ческому здравоохранению // Психофармакол., биол., наркол. 2007. - Т. 7, спец. вып. - Ч. 1.

5. Применение церебролизина при церебральном ишемическом инсульте: Метод. рекомендации / Под ред. члена-корр. РАМН, проф. В.И. Скворцовой. - М., 2006. - 25 с.

6. Верещагин Е.И. Современные возможности нейропротек- ции при острых нарушениях мозгового кровообращения и черепно- мозговой травме (обзор литературы) // Журанал интенсивной терапии. - 2006. - № 3. - С. 4-28.

7. Черний В.И., Колесников А.Н., Городник Г.А., Островая Т.В., Чернявский Р.И. Ишемия головного мозга в медицине критических

состояний. Нейропротекция (патофизиология, терминология, ха- рактеристика препаратов): Метод. рекомендации. - К., 2007. -

$72 \mathrm{c}$.

8. Черний В.И., Ельский В.Н., Городник Г.А., Колесников А.Н., Островая Т.В. Острая церебральная недостаточность. - Донецк: Издатель Заславский А.Ю., 2008. — 440 с. интенсивной терапии в острой фазе заболевания предусматривает проведение мониторинга неврологического статуса, исследование спектральной мощности ЭЭГ, изучение реактивности ЦНС в ответ на фармакологическое воздействие.

9. Компендиум 2005 - лекарственные препараты / Под ред. В.Н. Коваленко, А.П. Викторова. - К.: МОРИОН, 2005. - $1920 \mathrm{c}$.

10. Городецкий В.В., Верткин А.Л., Любшина О.В., Скворцо- ва В.И., Торшхоева Х.М. Недифференцированная терапия кома- тозных состояний на догоспитальном этапе // Лечащий врач. 2006. - № 5. - C. 13-19.

11. Чекман I.C. Метаболічні препарати в сучасній експериментальній та клінічній фармакології // Актуальні пи- тання фармацевтичної та медичної науки та практики: Зб. наук. ст. - Запоріжжя, 2002. - Вип. 8. - С. 11-17.

12. Рациональная нейропротекция. / И.Ф. Беленичев, В.И. Чер- ний, Ю.М. Колесников и др. - Донецк: Издатель Заславский А.Ю., 2009. - $262 \mathrm{c}$.

13. Беленичев И.Ф., Колесник Ю.М., Павлов С.П., Абрамов А.В., Бухтиярова Н.В. Митохондриальная дисфункция при церебральной патологии. Нейропротекция цереброкурином // Международный неврологический журнал. 2008. - № 4(20). - C. 23-29.

14. Белєнічев І.Ф., Мазур І.А. Порівняльна оцінка антиоксидантної i протиішемічної дії тіотріазоліну і пірацетаму та їх комбінації за умов експериментальної ішемії головного мозку // Експерим. фізіологія та біохімія. - 2001. - № 4. - С. 59-65.

15. Острова Т.В., Черній В.І., Шевченко А.І. Алгоритм діагностики реактивності ЦНС методами штучного інтелекту. Серія «Наука і освіта». - Донецьк: ІПШІ МОНУ і НАНУ, 2004. $-180 \mathrm{c}$.

16. Guidelines for the Management of Severe Traumatic Brain Injury // J. of Neurotrauma. 1997. - Vol. 14, № 8. - 450 p.

17. Островая Т.В., Черний В.И., Андронова 
И.А. Исследование реактивности ЦНС в ответ на фармакологическое воздействие (Тиоцетам) // Международный неврологический журнал. 2007. - № 2(12). - С. 53-62.

18. Острова Т.В., Черній В.І., Андронова
І.А. Особливості реакцій ЦНС у відповідь на фармакологічну дію в умовах гострої церебральної недостатності різного генезу // Нейронауки: теоретичні та клінічні аспекти. — 2006. - Т. 2, № 1-2. - C. $45-55$.

\title{
SUMMARY
}

\section{ROLE AND PLACE OF TIOCETAM IN STRATEGY OF NEUROPROTECTION IN SEVERE CCT AND ISCHEMIC STROKE}

\author{
Cherniy V.I. \\ Donetsk National Medical University named after M. Gorky, Ukraine
}

The question about the possible ways of pharmacological correction of the second damage of cerebral tissue in brain ischemia, trauma and hemorrhage is a topical one. Trophic dysregulation, biochemical and functional differentiation of neurons are the universal component of nervous tissue damage pathogenesis. Reparative therapy is directed on the improvement of plasticity of healthy tissue which surrounds the area of ischemic-damaged brain, on activation of polysynaptic connections formation, on the increase of density of receptors and traditionally includes nootropic preparations. The comatose state of patient is a contraindication to application of these agents, because they provide a stimulating action. The application of Tiocetam (combination of piracetam with thyotriazolinum) is perspective in solution of this problem. In intensive therapy of acute cerebral insufficiency caused by the severe craniocerebral trauma or brain stroke a problem of determination of terms of beginning of treatment by Tiocetam and criteria of choice of adequate dose of this preparation is a topical one. The method of determination of Tiocetam adequate dose is developed on the basis of comparison of methods of estimation of impairment of consciousness on Glasgow Coma Scale and integral quantitative analysis of level of disorganization of EEG-patterns with research of brain responsiveness to Tiocetam introduction.

Key words: tiasetam, ischemic stroke, cranial-cerebral travma.

\section{XÜLASə}

\section{AĞIR KəLLӘ-BEYIN TRAMASI Və İŞEMIK İNSULT ZAMANI NEYROPROTEKSIYYA STRATEGIYASINDA TIOSETAMIN ROLU VO YERI}

\author{
Çerni V.İ. \\ M.Qorki ad. Donesk milli tibb universiteti, Ukrayna
}

\begin{abstract}
Baş beynin işemiyası, travması və beynə qansızma zamanı beyin toxumasının ikincili zədələnməsinin mümkün farmakoloji korreksiyası yolları mövzusu aktual olaraq qalmaqdadır. Neyronların trofik disrequlyasiyası, biokimyəvi və funksional differensiasiyası sinir toxumasının zədələnməsinin patogenezinin universal komponentidir. Baş beynin infarkt sahəsini əhatə edən sağlam toxumanın plastikliyinin yaxşılaşdırılmasına, polisinaptik əlaqələrin əmələ gəlməsinin aktivasiyasına, reseptorların sıxlığının artmasına yönəlmiş reparativ terapiya nootrop preparatların tətbiqini özündə birləşdirir. Xəstənin komotoz vəziyyəti stimuləedici təsirə malik bu preparatların tətbiqinə əks göstərişdir. Bu problemin həlli üçün tiosetam preparatının təyini perspektivli sayılır (pirasetam və tiotriazolin kombinasiyası). Ağır KBT və ya beyin insultu səbəbli kəskin serebral çatmamazlığın intensiv terapiyası zamanı tiosetamla müalicənin başlanması vaxtının təyini və preparatın optimal dozasının seçilməsi problemi aktual olaraq qalmaqdadır. Qlazko şkalası ilə huşun pozulmasının qiymətləndirilməsi metodu və tiosetamın təyininə cavab olaraq beynin reaktivliyinin tədqiqi ilə EEQ patternin dezorqanizasiyas1 səviyyəsinin inteqral kəmiyyət baxımından analizi metodunun müqayisəsi əsasında tiosetamın adekvat dozasının təyin edilmə metodikası işlənib hazırlanmışdır.
\end{abstract}

Açar sözlər: tiosetam, işemik insult, kəllə-beyin travması.

Məqalə “Təxirəsalınmaz vəziyyətlər təbabəti” jurnalında çap edilmişdir. (2009, №3-4, səh. 22-23). 